\title{
Potential of the adolescents, suffering from inflammatory bowel disease, for overcoming difficulties and achieving the intended goals
}

\begin{abstract}
Introduction. Self-efficacy is one of the most important determinants of behavior of adults and adolescents. The degree of self confidence attributable to oneself in order to overcome the difficulties of life and to achieve one's goals, both in healthy subjects and patients, determines the size of the effort and perseverance in taking action. According to The World Health Organization till 2020, chronic diseases will be the major cause of disability, and can be one of the most costly health problems. Therapy of chronic illness on the threshold of adult life requires, in addition to a comprehensive medical approach, the patient's active participation in the implementation of the treatment process. Therefore, the potential of young people entering adult life with the burden of diagnosed disease may indicate the direction of education of the chronically ill adolescents.

Aim. The aim of this study was to assess the potential of young people, both healthy and diagnosed with a chronic disease, to overcome difficulties of life.

Material and methods. The study used a questionnaire and KompOs scale (Personal Competence Scale), a standardized test in the field of Health Psychology. The study included 80 subjects aged 15-18 years, 40 patients with inflammatory bowel disease treated in the IP-CZD in Warsaw and 40 healthy students from Rzeszow. The study used a questionnaire and KompOs scale (Personal Competence Scale), a standardized test in the field of Health Psychology. It allows the evaluation of such features in subjects such as strength and endurance needed to take action and then to continue it.

Results. For young people despite of their health state the age of majority is mainly associated with a sense of autonomy, pursuing the job and the sense of responsibility for themselves and their families, without arousing fear in any of those groups. Parents of adolescents with IBD, however, still show too excessive protectiveness, and only $32.5 \%$ of children has a different view on that in comparison with $82.5 \%$ a group of healthy children. The sum of the results obtained on a scale KompOs, in both studied groups is at the same level of average values, ( 6 sten). The differences can be seen in correlation with sociodemographic characteristics such as: place of residence, financial situation or fertility families. Youth without chronic disease burden had the average level of self-efficacy (sten 6), whereas young patients diagnosed with IBD had a higher sense of efficacy (sten 7). Children with IBD, residing in large cities, have a higher average number of points in both the overall scale and subscales KompOs like (strength, endurance) than their healthy peers.

Conclusions. Young people with non-specific inflammatory bowel disease have a greater sense of strength and perseverance than their peers. The statistical significance between the number of points was obtained in the KompOs scale in the city of $>100$ thousand. The financial situation of families is different in both groups, especially in the persistence subscale.
\end{abstract}

Keywords: chronic disease, inflammatory bowel disease, self-efficacy.

DOI: $10.1515 /$ pjph-2015-0003

\section{INTRODUCTION}

Polish scientific literature uses two terms to name changes taking place in all spheres of life of a person between childhood and adulthood: adolescence or growing up. During that time, biological and psychical processes become complete under the influence of a family, culture and subculture of a young person [1]. During that difficult time of development a young person, diagnosed with a chronic disease, is forced to face not only challenges of his/her own adolescence, but also symptoms of the disease and limitations that it imposes. The disease causes the acceptance of prolonged dependence on a family and lack of autonomy, as well as natural refusal to accept that situation, which sometimes causes anxiety and anger. The chronically ill adolescent faces a necessity of choosing the way of life that is adequate to limitations resulting from the disease, and confronting dreams and expectations with his/her capabilities $[2,3]$. In that situation some threats, affecting the effectiveness of a therapy, may appear, which on the one hand, consists in overestimation of the impact of the disease and a sense of resignation, and on the other hand, negation of limitations and establishing

\footnotetext{
${ }^{1}$ Institute of Nursing and Health Sciences, Medical Department, University of Rzeszow, Poland

${ }^{2}$ Children's Memorial Health Institute in Warsaw, Poland
} 
life goals that are sometimes impossible to achieve. To reduce the risk of complications caused by the patient himself it is required - besides comprehensive medical approach in a therapy of the chronically ill adolescent - that the patient participates actively in the implementation of the treatment process. A conviction about one's own competences and abilities to control unpleasant events increases the readiness to overcome dangers and conduces to coping with them. Such potential is the individual background for overcoming life's difficulties of young people - attaining adulthood with a luggage of a chronic disease diagnosed - and it may show the direction of education about the independent health control after attaining adulthood.

Inflammatory bowel disease is a group of chronic and incurable diseases, including ulcerative colitis (colitis ulcerosa), Crohn's disease - in Poland known as LeśniowskiCrohn's disease - and other unclassified forms. The occurrence of these diseases results from genetic, environmental and immunological conditions. We note constant increase in the incidence of the disease in the country and in the world $[4,5]$. According to the rates, the disease isdiagnosed in about $25 \%$ of the whole population of the ill adolescents and children [6]. The sick, who were diagnosed with the disease in their childhood, are a group that suffers the longest and hardest.

\section{AIM}

The aim of this study was to assess the potential of young people with inflammatory bowel disease to overcome life's difficulties, based on the personal competence test, KompOs, and to compare it with the potential of the healthy youth.

\section{MATERIAL AND METHODS}

The research included 80 persons at the age of 15-18 years. After obtaining the consent of the Bioethical Commission of the University of Rzeszow the Test was completed by 40 persons, who were the patients of a gastro-enterological clinic IP CZD in Warsaw, and were treated for inflammatory bowel disease (IBD), and 40 adolescents, students of schools in Rzeszow, with no chronic diseases diagnosed. Children at the age of 15-16 treated in IP CZD accounted for $40 \%$ of the examined and persons at the age of $17-18-60 \%$. In the group of the healthy adolescents, the rates as for the sex and age were the same $-50 \%$ each.

The KompOs scale is a standardized test from the field of Health Psychology, designed for children and adolescents, both sick and healthy. The scale consists of two subscales - both of them include six statements, a half of them positive and the other half - negative. The respondents chose the most appropriate answers: "how they usually behaved" in a difficult situation or "when they were about to do something that was important for them", by choosing one of the four answers. Two factors singled out in the scale: strength and persistence refer to Kuhl's conception of will [7]. The strength (subscale A) is necessary for initiating an action, and persistence (subscale B) is essential for continuing it. The adolescents' participation in the examination was voluntary and anonymous. The research was conducted in the $1^{\text {st }}$ semester of 2012. The questions also concerned the place of residence, material situation and the number of children in families, education of parents and associations with attaining adulthood. The general result of a sense of one's own competence was presented in a form of points received in separate subscales, and they were additionally converted into standardized units of the sten scale, KompOs, for the interpretational purposes. The results of 1-4 stens are treated as low (12-30 points), 5-6 as average (31-36 points) and $7-10$ as high (37-48 points). The low results indicate a sense of low efficacy. The higher the result - the higher the sense of self-efficacy. To analyze the received data we used such descriptive statistics measures as percentage fractions, arithmetic mean for calculating mean value and T-student test for independent tests in order to determine the statistical significance of the differences between the two mean values.

\section{RESULTS}

We received 80 correctly completed tests. The number of girls and boys in the examined group with the inflammatory bowel disease was almost the same; there were only $10 \%$ more boys than girls.

The biggest group among the youth with IBD $-40 \%$ lived in small cities, whereas, $1 / 4$ of them $(25 \%)$ in big cities. More than a half of the young people from the control group lived in Rzeszow, $27 \%$ in villages and $15 \%$ in small cities. More than a half of the examined students with IBD attended high schools, $20 \%$ went to technical schools, $15 \%$ were junior high school students, and only $7.5 \%$ were vocational school students; $5 \%$ of them had individual education because of their health state. In the group of the healthy adolescents as much as $80 \%$ were students of high schools, $15 \%$ of them attended technical schools and $2.5 \%$ vocational schools and junior high schools (Figure 1).

The differences between education levels of the examined youth's parents were noted, especially at the level of higher education, where the group of mothers and fathers of the healthy children with higher education was two times bigger.

The received data related to concerns and challenges that the respondents associated with attaining the adulthood indicated only slight differences. Irrespective of their health state, they associated the adulthood mostly with a sense of independence, finding a job, and responsibility for themselves

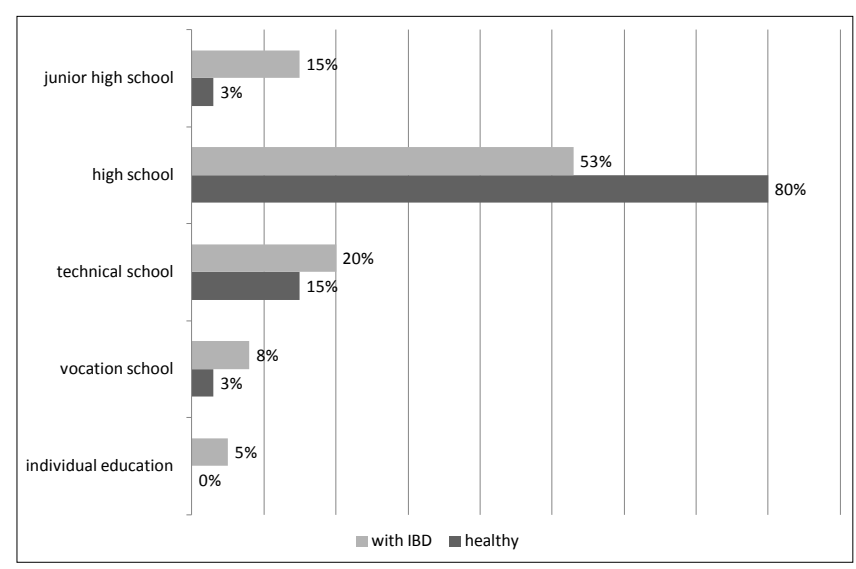

FIGURE 1. School status. 


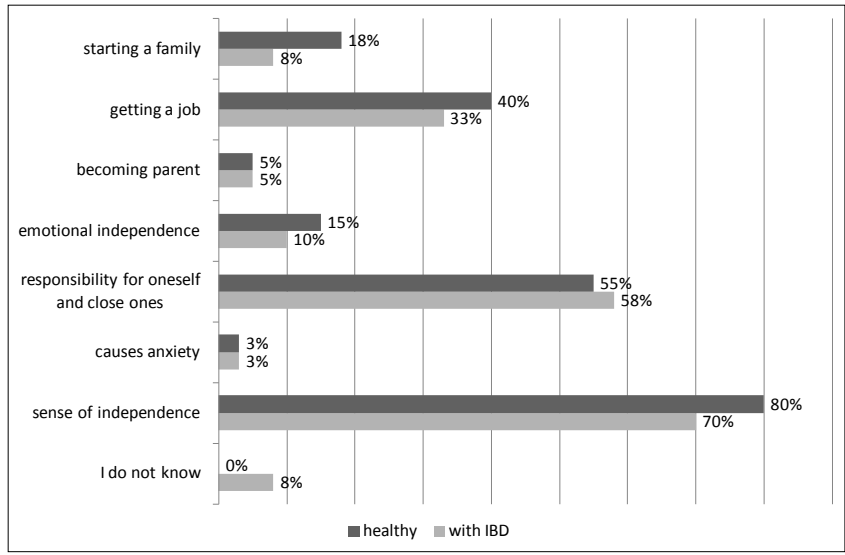

FIGURE 2. Associations with adulthood.

and their close ones, and neither group found it frightening (Figure 2).

Based on the sum of the results received in the KopmOs scale, the values in case of children with IBD and healthy children at the age of 15-18 were at the level of 6 stens (3436 ). Thus, the health state in that age group did not differentiate the respondents and a general sense of self-efficacy in both groups had mean values (Table 1). The differences are visible only in correlation with socio-demographical features, such as the place of residence, material situation or the number of children in a family.

It was shown that gender did not affect the level of a sense of one's own competence, and both girls and boys in both groups had similar results and were in the range determined as average.
TABLE 1 . The general result of a sense of self-efficacy.

\begin{tabular}{lcccccccc}
\hline \multirow{2}{*}{ Scale } & \multicolumn{3}{c}{ Healthy C hildren } & \multicolumn{4}{c}{ Children with IBD } \\
\cline { 2 - 9 } & $\mathrm{M}$ & $\min$ & $\max$ & $\mathrm{SD}$ & $\mathrm{M}$ & $\min$ & $\max$ & $\mathrm{SD}$ \\
\hline $\mathrm{A}$ & 17.90 & 9 & 24 & 3.81 & 19.03 & 10 & 23 & 2.98 \\
\hline $\mathrm{B}$ & 16.85 & 6 & 24 & 4.00 & 17.33 & 8 & 24 & 3.63 \\
\hline $\begin{array}{l}\text { General } \\
\text { result }\end{array}$ & 34.75 & 22 & 46 & 5.54 & 36.35 & 24 & 45 & 5.08 \\
\hline
\end{tabular}

The analysis of the received data showed that the children in the younger age group differed in the level of mean values for the general result of the KompOs scale. The adolescents without a chronic disease had the average level of selfefficacy (sten 6), and the level in the group with IBD was high (sten 7) (Table 2).

There is a noticeable difference in the subjective assessment of material situation among the examined respondents in both groups. In the population of the youth with IBD, as much as $60 \%$ of them assessed it as average, $27.5 \%$ good, only 1 person $(2.5 \%)$ as very good, and $10 \%$ as difficult. In the group of healthy children, only every fourth examined thought that the material situation of their family is average, the other $75 \%$ assessed it as good or very good.

It was also rated how often parents of the examined showed overprotective attitude in the opinion of the respondents. Only $32.5 \%$ of the children with IBD thought that their parents were overprotective, in comparison to $82.5 \%$ of the healthy children. However, after analyzing the questionnaires of the healthy children and children with IBD, who claimed that their parents were overprotective, it turned out that they had the same result of sten 6 , thus, the average level.

TABLE 2. The results of the KompOs scale in correlation with the age of the examined.

\begin{tabular}{|c|c|c|c|c|c|c|c|c|c|c|c|}
\hline \multirow{2}{*}{ Age } & \multirow{2}{*}{ Scale } & \multicolumn{4}{|c|}{ Healthy Children } & \multicolumn{4}{|c|}{ Children with IBD } & \multirow{2}{*}{ d } & \multirow{2}{*}{$\mathrm{p}$} \\
\hline & & $\mathrm{N}$ & $\%$ & $\mathrm{M}$ & SD & $\mathrm{N}$ & $\%$ & M & SD & & \\
\hline \multirow{3}{*}{$15-16$} & A & \multirow{3}{*}{20} & \multirow{3}{*}{$50.0 \%$} & 16.90 & 4.27 & \multirow{3}{*}{16} & \multirow{3}{*}{$40.0 \%$} & 18.94 & 3.21 & 2.04 & 0.12 \\
\hline & B & & & 17.10 & 4.17 & & & 18.38 & 3.67 & 1.28 & 0.34 \\
\hline & General result & & & 34.00 & 6.57 & & & 37.31 & 5.45 & 3.31 & 0.11 \\
\hline \multirow{3}{*}{$17-18$} & A & \multirow{3}{*}{20} & \multirow{3}{*}{$50.0 \%$} & 18.90 & 3.09 & \multirow{3}{*}{24} & \multirow{3}{*}{$60.0 \%$} & 19.08 & 2.89 & 0.18 & 0.84 \\
\hline & B & & & 16.60 & 3.91 & & & 16.63 & 3.50 & 0.03 & 0.98 \\
\hline & General result & & & 35.50 & 4.32 & & & 35.71 & 4.83 & 0.21 & 0.88 \\
\hline
\end{tabular}

TABLE 3. The results of the KompOs scale taking into account the place of residence.

\begin{tabular}{|c|c|c|c|c|c|c|c|c|c|c|c|}
\hline \multirow{2}{*}{$\begin{array}{l}\text { Place of } \\
\text { residence }\end{array}$} & \multirow{2}{*}{ Scale } & \multicolumn{4}{|c|}{ Healthy Children } & \multicolumn{4}{|c|}{ Children with IBD } & \multirow{2}{*}{$\mathrm{d}$} & \multirow{2}{*}{$\mathrm{p}$} \\
\hline & & $\mathrm{N}$ & $\%$ & M & SD & $\mathrm{N}$ & $\%$ & M & $\mathrm{SD}$ & & \\
\hline \multirow{3}{*}{$\begin{array}{l}\text { Small city } \\
(<100,000)\end{array}$} & A & \multirow{3}{*}{6} & \multirow{3}{*}{$15.0 \%$} & 19.33 & 3.83 & \multirow{3}{*}{16} & \multirow{3}{*}{$40.0 \%$} & 18.38 & 3.34 & 0.95 & 0.57 \\
\hline & $\mathrm{B}$ & & & 18.33 & 3.78 & & & 16.19 & 3.73 & 2.14 & 0.24 \\
\hline & General result & & & 37.67 & 6.47 & & & 34.56 & 5.10 & 3.11 & 0.25 \\
\hline \multirow{3}{*}{$\begin{array}{c}\text { Large city } \\
(>100,000)\end{array}$} & A & \multirow{3}{*}{23} & \multirow{3}{*}{$57.5 \%$} & 17.52 & 3.72 & \multirow{3}{*}{10} & \multirow{3}{*}{$25.0 \%$} & 20.50 & 2.17 & 2.98 & $0.3^{*}$ \\
\hline & $\mathrm{B}$ & & & 16.65 & 3.31 & & & 19.80 & 2.74 & 3.15 & $0.1^{*}$ \\
\hline & General result & & & 34.17 & 5.82 & & & 40.30 & 3.50 & 6.13 & $0.0 * *$ \\
\hline \multirow{3}{*}{ Village } & A & \multirow{3}{*}{11} & \multirow{3}{*}{$27.5 \%$} & 17.91 & 4.18 & \multirow{3}{*}{14} & \multirow{3}{*}{$35.0 \%$} & 18.71 & 2.87 & 0.8 & 0.57 \\
\hline & B & & & 16.45 & 5.43 & & & 16.86 & 3.42 & 0.41 & 0.82 \\
\hline & General result & & & 34.36 & 4.27 & & & 35.57 & 4.73 & 1.21 & 0.52 \\
\hline $\begin{array}{l}\text { statistical sign } \\
N \text { - number } \\
\text { - strength in }\end{array}$ & $\begin{array}{r}\text { ificance at the level } \\
M-\text { arithn } \\
\text { lex (result of the fir }\end{array}$ & $\begin{array}{l}\alpha=0.05 ; \\
\text { ic mean } \\
\text { ubscale) }\end{array}$ & & $\begin{array}{l}* * \text { statisti } \\
\text { SD - stan } \\
\text { B - persis }\end{array}$ & $\begin{array}{l}\text { nifican } \\
\text { leviatio } \\
\text { index ( }\end{array}$ & e lev & $\alpha=0.01$ & & $\begin{array}{l}\text { end } \\
\text { erence }\end{array}$ & n mean & \\
\hline
\end{tabular}


It was also noted that the children living in the villages, both healthy and sick, showed similar level of a sense of one's own competence. Based on the sten scale, the healthy children living in small cities were qualified to the high level (sten 7) and children with IBD to the average level (sten 6). Whereas, it was noted that in large cities children with IBD showed the level of the average number of points in the KompOs scale and in subscales (strength, persistence) that was higher than in case of their healthy peers. Additionally, the differences between the mean values showed statistical significance (Table 3).

Moreover, the examined group of adolescents differed due to the strength of a sense of self-efficacy with regard to their material situation. The differences between mean values showed statistical significance. The youth with IBD assessing their family material situation as average were at the level of sten 6 , which indicated the upper boundary of the average assessment of self-efficacy compared with the position of sten 4 among their healthy peers, which indicated low values (Table 4).

Moreover, it turned out that the same group of respondents with IBD, raised in families with three or four children, got the high level of efficacy compared with the average level in case of the healthy youth (Table 5).

\section{DISCUSSION AND SUMMARY}

In the light of the theoretical conceptions and research studies conducted on their basis, the efficacy and persistence in action in the process of achieving one's goals are conditioned by various factors. J. Kuhl studied the action control, commonly known as the will power. He distinguished the orientation on state and action. People with the orientation on state have problems with self-discipline and strong will. The orientation on action is opposite to the orientation on state. People with this kind of orientation are perceived as having strong will. They have no difficulties with starting implementation of their intentions, they can forget about failures and defeats. They are persistent in what they do. They belong to the group of people, who are more confident in setting their goals and more persistent in their implementation. In the opinion of Kuhl et. al., the control of action also gives the potential in the face of threat of failure, difficulties or everyday unpleasantness $[7,8]$. The analysis of the data did not show the adolescents' helplessness caused by their chronic disease. The teenagers with IBD did not differ from their healthy peers. Despite constant struggle with the disease symptoms, they achieved the same (average) level of personal competence, and at the same time, some of the

TABLE 4. The results of the KompOp scale taking into account the material situation of a family in the opinion of the adolescents.

\begin{tabular}{|c|c|c|c|c|c|c|c|c|c|c|c|}
\hline \multirow{2}{*}{$\begin{array}{l}\text { Material } \\
\text { situation }\end{array}$} & \multirow{2}{*}{ Scale } & \multicolumn{4}{|c|}{ Healthy Children } & \multicolumn{4}{|c|}{ Children with IBD } & \multirow{2}{*}{$\mathrm{d}$} & \multirow{2}{*}{$\mathrm{p}$} \\
\hline & & $\mathrm{N}$ & $\%$ & M & $\mathrm{SD}$ & $\mathrm{N}$ & $\%$ & M & $\mathrm{SD}$ & & \\
\hline \multirow{3}{*}{ Very good } & A & \multirow{3}{*}{11} & \multirow{3}{*}{$27.5 \%$} & 17.36 & 4.23 & \multirow{3}{*}{1} & \multirow{3}{*}{$2.5 \%$} & 20.00 & 0.00 & 2.64 & 0.56 \\
\hline & $\mathrm{B}$ & & & 18.00 & 4.34 & & & 21.00 & 0.00 & 3.0 & 0.52 \\
\hline & General result & & & 35.36 & 6.76 & & & 41.00 & 0.00 & 5.64 & 0.44 \\
\hline \multirow{3}{*}{ Good } & A & \multirow{3}{*}{19} & \multirow{3}{*}{$47.5 \%$} & 18.95 & 3.29 & \multirow{3}{*}{11} & \multirow{3}{*}{$27.5 \%$} & 19.09 & 2.74 & 0.14 & 0.90 \\
\hline & B & & & 17.84 & 3.27 & & & 17.27 & 2.97 & 0.57 & 0.64 \\
\hline & General result & & & 36.79 & 4.29 & & & 36.36 & 4.46 & 0.43 & 0.80 \\
\hline \multirow{3}{*}{ Average } & A & \multirow{3}{*}{10} & \multirow{3}{*}{$25.0 \%$} & 16.50 & 4.09 & \multirow{3}{*}{24} & \multirow{3}{*}{$60.0 \%$} & 18.88 & 3.35 & 2.38 & 0.09 \\
\hline & $\mathrm{B}$ & & & 13.70 & 3.50 & & & 17.50 & 3.78 & 0.20 & $0.01 *$ \\
\hline & General result & & & 30.20 & 3.65 & & & 36.38 & 5.54 & 6.18 & $0.00 * *$ \\
\hline \multirow{3}{*}{ Difficult } & A & \multirow{3}{*}{0} & \multirow{3}{*}{$0.0 \%$} & - & - & \multirow{3}{*}{4} & \multirow{3}{*}{$10.0 \%$} & 19.50 & 1.91 & - & - \\
\hline & $\mathrm{B}$ & & & - & - & & & 15.50 & 4.80 & - & - \\
\hline & General result & & & - & - & & & 35.00 & 4.97 & - & - \\
\hline
\end{tabular}

TABLE 5. The result of the KompOs scale taking into account the number of children in a family.

\begin{tabular}{|c|c|c|c|c|c|c|c|c|c|c|c|}
\hline \multirow{2}{*}{$\begin{array}{l}\text { Number of } \\
\text { children } \\
\text { in a family }\end{array}$} & \multirow{2}{*}{ Scale } & \multicolumn{4}{|c|}{ Healthy Children } & \multicolumn{4}{|c|}{ Children with IBD } & \multirow{2}{*}{$\mathrm{d}$} & \multirow{2}{*}{$\mathrm{p}$} \\
\hline & & $\mathrm{N}$ & $\%$ & M & SD & $\mathrm{N}$ & $\%$ & M & $\mathrm{SD}$ & & \\
\hline \multirow{3}{*}{ Up to 2} & A & \multirow{3}{*}{29} & \multirow{3}{*}{$72.5 \%$} & 18.00 & 4.16 & \multirow{3}{*}{23} & \multirow{3}{*}{$57.5 \%$} & 18.52 & 3.13 & 0.52 & 0.62 \\
\hline & $\mathrm{B}$ & & & 16.93 & 4.17 & & & 17.43 & 3.94 & 0.5 & 0.66 \\
\hline & General result & & & 34.93 & 5.82 & & & 35.96 & 5.24 & 1.03 & 0.51 \\
\hline \multirow{3}{*}{3 or 4} & A & \multirow{3}{*}{11} & \multirow{3}{*}{$27.5 \%$} & 17.64 & 2.87 & \multirow{3}{*}{14} & \multirow{3}{*}{$35.0 \%$} & 19.50 & 2.90 & 1.86 & 0.12 \\
\hline & $\mathrm{B}$ & & & 16.64 & 3.67 & & & 17.71 & 2.76 & 1.07 & 0.41 \\
\hline & General result & & & 34.27 & 4.96 & & & 37.21 & 5.12 & 2.94 & 0.16 \\
\hline \multirow{3}{*}{ More than 4} & A & \multirow{3}{*}{0} & \multirow{3}{*}{$0.0 \%$} & - & - & \multirow{3}{*}{3} & \multirow{3}{*}{$7.5 \%$} & 20.67 & 1.53 & - & - \\
\hline & $\mathrm{B}$ & & & - & - & & & 14.67 & 4.93 & - & - \\
\hline & General result & & & - & - & & & 35.33 & 4.73 & - & - \\
\hline $\begin{array}{l}\text { statistical sign } \\
\mathbf{N} \text { - number } \\
\text { - strength in }\end{array}$ & $\begin{array}{l}\text { ificance at the level } \\
M-\text { arithn } \\
\text { lex (result of the fir }\end{array}$ & $\begin{array}{l}\alpha=0.05 ; \\
\text { ic mean } \\
\text { ubscale) }\end{array}$ & & $\begin{array}{l}* * \text { statist } \\
\text { SD - stan } \\
\text { B - persi }\end{array}$ & $\begin{array}{l}\text { nifican } \\
\text { leviatio } \\
\text { index ( }\end{array}$ & e lev & nd subse & & $\begin{array}{l}\text { end } \\
\text { erence }\end{array}$ & mean & \\
\hline
\end{tabular}


socio-demographic factors caused the movement towards higher level. It is the information that may be the starting point for the workers of health care system in case of the patients waiting for a transfer to physicians for adults. It shall be remembered that at the moment of turning 18 years of age, the previous pediatric care, often of a family nature, will be changed into the model that expects the patient's autonomy and independence. Therefore, the strength and persistence in setting one's goals will be important in the individual's life with regard to their future roles and dangers caused by a chronic disease.

The studies of Gromulska on health behaviors in case of a chronic disease showed that the motivation for prohealthy behaviors is higher if the patient expects better effects of treatment and of his own participation in this treatment [9]. Whereas, Sansone and Harackiewicz indicate the need to distinguish two kinds of causes, which are important for starting any action, as well as for its persistent continuation. The authors suggest that it is important to distinguish implementation of complex and long-term goals in case of which the most important for persistence is the way of the individual's experiencing the action [10]. Persons oriented on action know what to do, but they also know how and why they should do it [11].

This paper assesses the issue of a role of self-efficacy in young people, whose everyday life is - and will be accompanied by a chronic disease. The received results indicate the need for conducting further researches, also among children with other chronic diseases, as we may presume that in the group of adolescents, but also adults, people with a high sense of self-efficacy will set high goals and aim at their implementation [12]. It is true that there are more and more data on the life quality of children and adolescents with chronic diseases; however, we cannot state their level of strength and persistence because of a lack of such studies. The generalized self-efficacy of adults is measured by the GSES scale (Generalized Self-Efficacy Scale), which may be soon used for the group of adolescents [13].

\section{CONCLUSIONS}

1. The adolescents with chronic disease show higher sense of strength and persistence than their healthy peers. It mostly refers to the patients living in the cities $>100,000$ citizens.

2. The family material situation is different for both groups, especially in the subscale determining persistence.

3. The adolescents with IBD assessing their material situation as average, at the same time, living in multi-child families, have higher sense of self-efficacy than their healthy peers.

\section{REFERENCES}

1. Harwas-Napierała, B, Trempała J. Psychologia rozwoju człowieka. Charakterystyka okresów życia. Warszawa: Wydawnictwo Naukowe PWN; 2004.

2. Pilecka W. Zmagania się dziecka z przewlekłą chorobą somatyczną od radzenia sobie do transcendencji. In: B. Antoszewska (ed). Dziecko przewlekle chore - problem medyczne, psychologiczne i pedagogiczne. Torun: Wydawnictwo Edukacyjne Akapit; 2011.

3. Skrzypek M. Perspektywa chorego w socjologii choroby przewlekłej. Lublin: Wydawnictwo KUL; 2011.

4. Laszlo P. Recent trends in the epidemiology of inflammatory bowel diseases: Up or down? World J Gastroenterol. 2006;12(38):6102-8.

5. Rejestr choroby Leśniowskiego-Crohna. [www.chorobacrohna.pl] (25.02.2013)

6. Bickston SJ, Bloomfeld RS. Nieswoiste zapalenia jelit. In: G. Rydzewska (ed.) Wrocław: ELSEVIER Urban \& Partner; 2013.

7. Kuhl J. Who controls whom "when I control myself”? Psychol Inq. 1996;7(1):61-8.

8. Kuhl J, Kazen M, Koole SL. Putting self-regulation theory into practice. Int Rev. 2006;55:408-18.

9. Gromulska L, Piotrowicz M, Canciara D. Własna Skuteczność w modelach zachowań zdrowotnych oraz w edukacji zdrowotnej. Przegl Epidemiol. 2009;63:427-32.

10. Sansone C, Harackiewicz JM. "I don't feel like it". The function of interest in self -regulation. In: L. L. Martin, A. Tesser (ed). Interactions among goals, affect, and self-regulation. New Jersey: Lawrence Erlbaum; 1996. p. 175-202.

11. Kadzikowska-Wrzosek R. Wytrwałość i skuteczność działania: wpływ kontekstu sytuacyjnego i siły woli. Rocz Psychol. 2011;XIV(2):159-86.

12. Juczyński Z. Poczucie własnej skuteczności jako wyznacznik zachowań zdrowotnych. Prom Zdr. Nauki Społ Med. 1998;14:54-63.

13. Juczyński Z. Narzędzia pomiaru w promocji i psychologii zdrowia. Warszawa: Pracownia Testów Psychologicznych PTP; 2011.

\section{Corresponding author}

Katarzyna Wardak

12 Sportowa Str., \#16, 35-111 Rzeszów

tel.: 698-237-003

E-mail: wardakk@interia.pl

The article has been founded with support from the project "Innovative University of Rzeszow", implemented through the MNiSW programme "Innovativeness Creator - Support for Innovative Academic Initiative" under the agreement No. 13/PMKI/U/11.09/2010 from October 27, 2010. 